level being the most significant. The inequality of perceptual sensations, as well as the different number of linguistic signs of their expression, is reflected in the vocabulary of the language. Linguists suggest that there is more lexical differentiation for visual concepts than for the other senses.

Sensory words belong to different parts of speech: nouns, adjectives, verbs, and adverbs, since all words perform a nominative function. Perceptual features expressed by nouns are objectified; adjectives express perceptual features that do not evolve in time and are inseparable from objects; verbs express dynamic perceptual features, and adverbs express perceptual features as secondary qualities, i.e. qualities of another (dynamic or static) quality.

Perceptuality can be regarded as a linguistic category. In sensory linguistics, the basic notion is "sensory", which is used along with the notion "perceptual". However, in the English tradition, the notion "sensory" is associated with sensation, and the notion "perceptual" - with perception. Linguists use the term "perceptual mode" to refer to a particular type of sensation. The terms denoting perceptual modalities are of Latin origin: "visual", "audible", "tactile" ("haptic"), "olfactory", and "gustatory".

Other frequently used terms are "sensory experience", "percipient", and "experimenter". The term "percipient' presupposes the actual, available sensory experience gained "here and now", and the term "experimenter" - the total sensory experience accumulated during a person's life.

Key words: sensory linguistics, perceptuality, perceptual mode, sensory vocabulary, part of speech.

DOI: https://doi.org/10.32782/2410-0927-2020-12-20

УДК 811.111(73)’42Тарантіно:791.222.43

Малімон Леся, Барило Яна

\title{
ЛІНГВОКОГНІТИВНІ ОСОБЛИВОСТІ КІНОДИСКУРСУ ТВОРІВ КВЕНТІНА ТАРАНТІНО (НА МАТЕРІАЛІ ФІЛЬМУ “БЕЗСЛАВНІ ВИРОДКИ")
}

Стаття присвячена аналізу особливостей кінодискурсу творів режисера Квентіна Тарантіно на матеріалі фільму “Безславні виродки”. Поняття “кінодискурс" розглядається як комплексне, що включає в себе велику кількість аспектів та складових, а саме вербальних, невербальних та екстралінгвальних. У статті досліджено специфічні риси кінодискурсу цього фільму як окремо взяті, так і ті, що формують неповторний режисерський стиль та повторюються в багатьох фільмах Тарантіно. На думку авторів, аналіз кінодискурсу та сам факт виділення його серед інших видів дискурсу є ключовим для розуміння багатьох факторів комунікації, оскільки кіно як мистецтво є засобом відтворення реальності та соціального пізнання. Останні ж, зі свого боку, піддаються впливу кінодискурсу. У статті доведено, що головними та яскраво вираженими рисами кінодискурсу цього фільму є інтертекстуальність, цілісність, широке використання підтексту та створення ефекту саспенсу, при чому більшість із цих ознак $\epsilon$ взаємопов'язаними та виступають як результат впливу окремих мовних явищ. Ці характерні риси виступають як засоби передачі інформації (вербальної, невербальної або ж екстралінгвальної), допомагають правильно інтерпретувати внутрішні почуття мовців у певній ситуації та зрозуміти їхнє бачення цих ситуацій, сприйняття інших мовців чи об'єкта дискусії. Автори наголошують, що всі раніше згадані риси, а саме: використання багатьох мов, перемикання мовних кодів, застовування вербальних маніпуляцій, велика кількість сюжетних ліній, які зрештою мають об'єднатись в одне, формують структуру, стиль та розуміння кінокартини. Кінотекст є важливою складовою в синтетичній структурі кіно, поруч із такими значущими для смислової та естетичної завершеності екстралінгвальними складовими, як візуальний ряд, звукова інформація, візуальні та механічні спеціальні ефекти, комп'ютерна графіка та ін. Стаття звертає увагу на важливість аналізу кінодискурсу у світлі збільшення впливу, i, як наслідок, популярності й релевантності мистецтва кіно, яке на сьогодні є не лише розвагою чи частиною масової культури, але й засобом впливу на комунікацію та соціальне пізнання; а окремі фільми є важливою складовою світового кіноресурсу та кінодискурсу.

Ключові слова: кінодискурс, підтекст, саспенс, інтертекстуальність, мовний код.

Вступ Кінематограф є одним з наймолодших та, безсумнівно, найпоширеніших видів мистецтва, що набуває дедалі більшого визнання у світі як перспективний предмет дослідження. В епоху візуалізації інформації суто вербальні тексти відходять на другий план, поступаючись місцем медіатексту. Саме кіно стає визнаним засобом відображення реальності, соціального пізнання та водночас розвагою.

Яскравою характерною рисою життя сучасної людини є мультитаскінг, тобто виконання та сприйняття кількох дій чи розумових операцій одночасно. Кіно створюється за подібним принципом: це поєднання візуальної інформації, медіатексту, звукової інформації та технологій.

(С) Малімон Л., Барило Я., 2020 
Мистецтво має бути сучасним, іти в ногу зі світом та його трендами. Власне, кінематограф став породженням своєї епохи, оскільки він розвивається разом зі світом, технологічним прогресом та способами комунікації.

Оскільки дискурс є відтворенням повсякденної комунікації, соціального контексту та має на них вплив [5, с. 112-113], кінофільм можна розглядати як медіатекстове утворення, яке входить у кінодискурс та, відповідно, також відтворює повсякденне спілкування [14, с. 137]. Кінодискурс поєднує не лише вербальну інформацію, але й невербальну (міміку, жести, мову тіла) та екстралінгвальну. У цьому випадку візуальний ряд, звукове оформлення та спецефекти (CGI) можуть сприйматись як фактори екстралінгвальної дистрибуції.

Вагомий вклад у розвиток кінематографа майже 3 самого початку його заснування зробили американські картини та кінодискурс, i ось уже кілька десятиліть поспіль вони зберігають репутацію одного з найбільших світових кіноресурсів завдяки великій кількості режисерів та престижних кінопремій. Матеріалом дослідження обрано фільм одного 3 найталановитіших та найбільш визнаних американських режисерів Квентіна Тарантіно “Безславні виродки”.

Кве́ нтін Джеро м Тарантіно(англ. Quentin Jerome Tarantino; народився 27 березня 1963) американський режисер, сценарист, актор і продюсер. Став відомий на весь світ після фільму “Кримінальне чтиво” (1994), який приніс йому “Золоту пальмову гілку” Каннського кінофестивалю, а також премії “Оскар” і “Золотий глобус” за найкращий сценарій.

Метою цієї наукової розвідки $є$ встановити та проаналізувати лінгвокогнітивні особливості, характерні для кінодискурсу творів Квентіна Тарантіно на прикладі картини "Безславні виродки" шляхом дослідження вербальних, невербальних та екстралінгвальних аспектів. "Безславні виродки" (англ. Inglourious Basterds) - шостий фільм режисера, у якому він також виступив сценаристом. Події картини відбуваються у Франції під час Другої світової війни. Фільм оповідає про групу американсько-єврейських солдатів-месників (Виродків), яку наймає французький рух Опору та про єврейку Шошанну Дрейфус, котра дивом рятується від нацистського рейду.

Аналіз попередніх досліджень і публікацій, у яких започатковано вивчення проблем кінодискурсу показав, що одним із перших, хто запропонував розглядати як об'єкт аналізу твір кіномистецтва, був Ю. М. Лотман, зокрема він вивчав кінокартини 3 погляду семіотики та виділив такі елементи кінотексту, як кадр та кінофраза. Такі дослідники, як Ю. Цив'ян [17], Г.Г. Слишкін [15], присвятили чималу увагу вивченню питань лінгвокультурного аналізу кінодискурсу, його екстралінгвальних компонентів, а також особливостей кіномови. Л.В.Цибіна, Б. Браун та С. Коструп розглядали лінгвістичні, екстралінгвальні компоненти кінодискурсу та особливості поняття кінотексту.

Кінодискурс 3 точки зору мультимодального семіотичного явища [1, с. 139] розглядається як сукупність рухливих і статичних образів, усного і письмового мовлення, поособливиму організованих аудіоелементів, а також включають лінгвальну та нелінгвальну семіотичні системи $[21$, с. 21$]$.

Iз позиції семіотики кінодискурс аналізують західні лінгвісти, зокрема, П.Воллен стверджував, що в кінодискурсі роль знаків-ікон значно важливіша за роль знаків-індексів, а семіологи й лінгвісти перебільшують значення знаків-символів [19, с. 116]. Таким чином, у межах семіотичної теорії кінодискурс трактується як єдність і синтез мовних і немовних знаків, у якій знаки-індекси включають інтонацію, вигуки, шуми (природні й технічні), саундтреки, візуальний ряд, а знаки-символи, як правило, представляють мовний компонент - титри, написи в самому фільмі (письмові), мова акторів, закадровий текст (усні) [6, с. 103]. Семіотичний аналіз кінодискурсу базується на методологічній базі теорії дискурсу, а також лінгвістики, історії, міжкультурної комунікації, основні методи яких (методи дискурс-аналізу, семіотичний та інтерпретативний аналізи, метод інтроспекції) пояснюють взаємодію семіотичних підсистем. Кінодискурс як систему знаків досліджували С. Зайченко [10], Ю. Цив’ян [17], М. Ворошилова [18].

I. Коваленко стверджує, що кінодискурс — це "креолізована" єдність, що репрезентує семіотичний простір, власне текст і результат інтерсеміотичного перекладу [8, с. 50]. 
Варто відзначити дослідження Дж. Джекла, об’єктом яких був жанр та зумовлене ним використання вербальних елементів. Окрім цього, дослідник пропонує розмежовувати вербальну та візуальну складову фільмів та розробляє власну методику аналізу діалогу кіно [7, c. 7-11].

Кінодискурс як відміний від наративного тексту трактували М. Кун і Й. Шмідт, виявивши такі його характерні риси: візуально-аудіальний вимір наративної репрезентації, наявність кількох наративних структур, поєднаних монтажем, наявність мультимедіального оповідача, що включає специфічні кінематографічні прийоми та технології, встановлення причиново-наслідкової логіки розвитку подій навіть за відсутності послідовного наративного континууму, “подвійна хронологія/подвійна темпоральна логіка", за яких зовнішній вимір тривалість самого фільму, а внутрішній вимір - тривалість охоплюваних подій, жанрова та мовна стереотипізація та ін. [14, p. 384-405].

Незважаючи на достатньо велику кількість грунтовних досліджень із цієї проблеми, питання кінодискурсу все ще залишається не вичерпаним через наявність термінологічних розбіжностей. Окрім цього, кіно як мистецтво постійно піддається впливу суспільних перипетій, у результаті змінюючи й кінодискурс, який так чи інакше $\epsilon$ відтворенням реальної повсякденними комунікації. Простір для дослідження залишає також кінодіалог, який $\epsilon$ частиною кінодискурсу та окремим жанром.

Кінематограф постійно генерує все більше й більше медіатекстів, які є відображенням соціального життя, а кінодискурс продовжує диктувати свої цінності та критикувати вже наявні. Дискурс розвивається разом з технологіями, трендами в комунікації, способами подачі інформації та власне кіно, впливаючи на наявну реальність та будуючи нову. Питання кінодискурсу залишається невичерпним та релевантним саме через взаємовплив змін у суспільстві та мистецтві.

Методи дослідження. Насамперед звернемося до поняття дискурсу, сформоване одним iз провідних дискурсознавців Т. ван Дейком: “Дискурс - це складне комунікативне явище, яке включає в себе соціальний контекст, що дає уявлення про учасників комунікації, так і про процеси виробництва і сприйняття повідомлення" [5, с. 112-113].

Поняття "кінодискурс" виникло завдяки лінгвістичному аналізу кінотексту. Т. А. Крисанова вважає, що кінотекст - це "складний полікодовий медіатекст, який існує у формі кінофільму, поєднує загальнотекстові та специфічні характеристики, є завершеним витвором колективного автора і призначений колективному адресатові" [11, с. 99]. Щодо кінодискурсу, то науковиця А. Н. Зарецька стверджує, що це “пов'язаний текст, який $\epsilon$ вербальним компонентом фільму, а в сукупності 3 невербальними компонентами аудіовізуальним рядом цього фільму й іншими значущими для смислової завершеності фільму екстралінгвальними факторами, створеними колективно диференційованим автором для перегляду реципієнтом повідомлення" [21, с. 39]. Що ж до різниці між поняттями кінодискурсу та кінотексту, кінодискурс є більш широким поняттям, яке включає в себе як кінотекст, так $\mathrm{i}$ кінофільм, інтерпретацію його глядачем і той зміст, що вклали творці фільму. Крім того, поняття кінодискурсу включає також інтертукстуальні кореляції з різноманітними видами мистецтва та культурний контекст, у якому відбувається комунікація, тоді як кінотекст складається лише 3 вербальних та невербальних іï елементів [14, с. 137].

Важливою складовою фільму та власне кінодискурсу є підтекст, оскільки він може бути як вербальною, так і невербальною формою передачі інформації. Згідно з Літературознавчою енциклопедією Ю. Коваліва, підтекст — це інший план повідомлення, який створюється не довільно, а тими ж засобами, що й основний план.

До таких засобів належать:

- лексико-семантичні засоби (метафора, метонімія, перифраз, порівняння тощо);

- ситуативні засоби (факти, події, раніше згадані);

- асоціативні засоби (поняттєві, емоційні зв'язки, які виникають між тим, про що йдеться, і досвідом автора або реципієнта). 
Крім того, кожне слово має психологічний образ, властивий конкретному реципієнтові. Цей психологічний образ здатний викликати у свідомості реципієнта свій ланцюг асоціацій, на основі яких і створюється інший, прихований план повідомлення. Безперечно, не можна знати психологічних образів кожного читача, але можна прогнозувати підтексти 3 урахуванням оказіональних, нелітературних, розмовних, переносних значень слів [9, с. 215].

Доволі частим породженням та ціллю вербальних і невербальних маніпуляцій $є$ ефект саспенсу. Цей термін також існує в значенні кіножанру, визначеного Альфредом Гічкоком, однак ми розглядатимемо його в значенні стратегічного відкладання та однією 3 цілей кінодискурсу. Зокрема, О. С. Божко запевняє, що поняття "саспенс" $є$ комплексним поняттям, що характеризує ступінь наративної напруженості, створюваної двома модусами оповідання: стратегічною неповнотою (заснованою на невизначеності, що викликає в читача стан зацікавлення) i стратегічним відкладанням (пов'язаним 3 передчуттям, очікуванням, які індукують стан тривоги і занепокоєння). Атмосфера “саспенс" виникає тоді, коли розв'язка включає в себе найбільш ймовірну, хоча й небажану альтернативу, а читач сподівається на малоймовірний, але бажаний результат подій [4, с. 52-53].

Засобом створення додаткового відтінку значення та емоційного наповнення виступає також інтертекстуальність, функціонуючи на основі відсилання уваги глядача до певної події, твору мистецтва або ж викликаючи асоціацію. Дослідниця Юлія Крістева визначає інтертекстуальність як “текстуальну інтеракцію у межах окремого тексту” та “мозаїкою цитувань...вбиранням у себе й трансформацією якогось іншого тексту” [10, с. 429]. Концепція науковиці отримала широке визнання та забезпечила подальші перспективи досліджень, зокрема Р. Барт зазначає, що “будь який текст $є$ між-текстом щодо якогось іншого тексту...текст утворюється 3 анонімних, невловимих і водночас уже прочитаних цитат" [2, с. 417]. Таким чином, інтертекстуальність постає як невід'ємна риса будь якого тексту, а отже й кіно тексту також. До того ж, відсилання читача до певного твору чи явища може бути навмисним та виступати як специфічний прийом, покликаний занурити реципієнта у глибини авторського задуму чи викликати певні емоції, або ж випадковим та неусвідомленим.

У "Безславних виродках" доволі важливим елементом кінодискурсу, який виступає засобом створення саспенсу та підтексту є перемикання мовних кодів, тож варто згадати й це мовне явище. Наразі науковці по-різному трактують його. Більшість дослідників стверджують, що перемикання кодів - це "перехід мовця у процесі мовленнєвого спілкування з однієї мови (діалекту, стилю) на іншу залежно від умов спілкування" [3, с. 16].

Результати та дискусії. Для дослідження був обраний шостий фільм режисера Квентіна Тарантіто під назвою “Безславні виродки” (“Inglourious Basterds”) у жанрі альтернативної історії. Кінодискурс Тарантіно має низку яскраво виражених рис, за допомогою яких його фільми вирізняються серед інших. Зокрема, картини режисера відомі своєю цілісністю, створенням ефекту саспенсу, широким використанням підтексту.

Цілісність є важливим елементом як текстового, так і кінодискурсу, й “Безславні виродки" не $\epsilon$ винятком. У фільмі сплітаються сюжетні лінії єврейки Шошанни, банди Виродків та британського шпигуна Арчі Гікокса. Більшість із цих ліній сходиться в передфінальній сцені пожежі в кінотеатрі, де гинуть майже всі названі герої. Дії у фільмі відбуваються в різних частинах світу, однак поступово сходяться до одного місця, що є доволі типовим для кінодискурсу Тарантіно, і визначає цілісність або ж навіть і завершеність картини. Дослідниця В. А. Кухаренко відзначає: "Положення про закритість текстової системи добре узгоджується 3 категорією цілісності (завершеності), обов'язково притаманній цілому тексту... Автор насправді виступає як одноосібний хазяїн становища - “де вважаю за необхідне, там ставлю фінальну крапку”, що в свою чергу означає, що концепт сформований, шлях до його розуміння вказаний, повідомлення завершене, система закрита" [12, с. 54]. У “Безславних виродках" режисер не лише формує та закриває свій кінодискурс, але й інтегрується в нього. Наприкінці фільму Алдо Рейн, вирізавши свастику на лобі Ганса Ланди, схиляється, ніби дивлячись униз завдяки нижньому ракурсу зйомки, та промовляє: "I think this just might be my masterpiece", і одразу після цієї фрази з'являються титри зі словами "Written and directed by Quentin Tarantino". Завдяки екстралінгвальним засобам 
(способу монтажу) репліка Алдо сприймається ніби слова режисера про свій же фільм, який не лише вирішує, на якому моменті завершити картину, але й при цьому оцінити їі.

Інтертекстуальність набуває популярності в дискурсі загалом, не кажучи вже про кінодискурс, який є частиною синтетичного мистецтва кіно. Як відомо, більшість фільмів Тарантіно яскраво характеризує саме інтертекстуальність, оскільки режисер включає як кіноцитати з майже дослівним повторенням реплік героїв вестернів, так і алюзії на кадри 3 цих фільмів. До прикладу, друга частина «Безславних виродків» нагадує воєнний фільм “The Dirty Dozen" у плані сюжету та побудови сценарію, назва першої частини "Once upon a time... in Nazioccupied France" перегукується з назвою вестерну "Once Upon a Time in the West", а також алюзіi на власні фільми - нижній ракурс зйомки нападника, який спостерігає за своєю жертвою присутній наприкінці фільму, коли Алдо Рейн дивиться на Ганса Ланду. Цей екстралінгвальний прийом використовувався режисером у фільмах "Кримінальне чтиво”, “Джекі Браун”, “Убити Білла", “Скажені пси” та ін. Як бачимо, в сучасному кінематографі роль інтертекстуальних елементів, які мають визначати цільову аудиторію набуває надзвичайної важливості. Таким чином, успішність фільму як комунікативного акту багато в чому залежить і від розуміння та правильної інтерпретації інтертекстуальних зв'язків кінематографа” [22, с. 114].

Підтекст та імплікації трапляються у вигляді вербальних (іронізація, насмішки, маніпуляції), невербальних (жести героїв, мова їх тіла), а також екстралінгвальних засобів (предмети побуту, якими користуються герої, і навіть їжа). Згадаємо першу сцену фільму, у якій полковник Ганс Ланда розмовляє з Пер'єром ЛяПадітом. Запросивши офіцера СС до будинку, Пер’єр пропонує йому вина, однак Ланда просить натомість склянку молока:

PERRIER: Charlotte, would you be so good as to get the Colonel some wine?

COL LANDA: Merci be coupe Monsieur LaPadite, but no wine. This being a dairy farm one would be safe in assuming you have milk?

CHARLOTTE: Oui.

COL LANDA: Then milk is what I prefer.

CHARLOTTE: Very Well.

(stage directions) The mother of three, takes a craft of milk out of the ice box, and pours a tall glass of the fresh white liquid for The Colonel. The S.S. Colonel takes a long drink from the glass, then puts it down LOUDLY on the wooden table.

Незважаючи на те, що Ланда поводиться й говорить поштиво, він почувається в будинку ЛаПадітів господарем. Полковник з самого початку знав, що сім'я переховує євреїв, однак затягував розмову, запевняючи батька сім'ї, що це “лише формальність” і його візит не несе жодної загрози. Пізніше, після втечі Шошанни - єдиної з євреїв, яка вижила після візиту офіцера, вони з Гансом зустрічаються ще раз. Ланда затримав іiі, нібито щоб обговорити питання безпеки заходу, який відбуватиметься в ііі кінотеатрі, однак насправді він знав, хто вона, хоч і не виказав цього вербально. Натомість полковник удався до екстралінгвальних засобів, замовивши Шошанні склянку молока:

COL. LANDA: Yes, two strudels, one for myself, and one for the mademoiselle. A cup of espresso, with a container of steamed milk, on the side. For the Mademoiselle, a glass of milk.

(stage directions) Considering Shosanna grew up on a dairy farm, and the last time she was on a dairy farm, her strudel companion murdered her entire family, his ordering her milk is, to say the least... disconcerting. The key to Col Landa's power, and or charm, depending on the side ones on, lies in his ability to convince you he's privy to your secrets.

Жест повторював дію Ланди перед розстрілом іiі сім’ї та одразу ж викликав у дівчини підозру, занепокоєння, а також хвилю бентежних спогадів, виступаючи інтертекстуальним повторенням. Ланда не виказував того, що знає правду про Шошанну, вербально - натомість дозволяв своєю поведінкою можливість двозначного трактування. Лише одна його репліка створила неймовірне напруження та відчуття очікування, яке все ж залишало надію дівчині, адже вона не знала, чим може обернутись ця розмова. Саме це й створює неперевершений ефект саспенсу завдяки асоціативному підтексту, який викликала склянка молока - героїня Шошанни перебувала в нервовому очікуванні і була змушена боротись 3 панікою, у той же час вона 
намагалась не виказати себе невербально або ж вербально, що, можливо, дозволило б їй вийти 3 цієї ситуації безпечно.

3 іншої точки зору, натяк офіцера можна було б трактувати як вербальний (лексичний) підтекст, якщо відштовхуватись від фрази «For the Mademoiselle, a glass of milk», однак це викликало конкретний асоціативний образ лише в Шошанни і не мало би впливу на іншого персонажа, тому цей підтекст трактуємо як асоціативно-ситуативний, 3 екстралінгвальним способом вираження.

Невербальним висловленням підтексту є також істеричний сміх Ганса Ланди під час розмови з актрисою Бріджит фон Хаммерсмарк та трьома Виродками, які вдавали італійців, щоб пробратись на прем'єру нацистського фільму. Полковник знав, що фон Хаммерсмарк працює на американців і що за день до цього вона зустрілась у пабі з двома Виродками та британським шпигуном Арчі Гікоксом, які планували диверсійну діяльність, однак були викриті. Зустріч закінчилась жорстокою баталією та смертю всіх, окрім Бріджит, яка внаслідок цього травмувала ногу. Офіцер помічає гіпс на нозі актриси і одразу про це запитує:

COL.LANDA: Seriously, what happened?

BRIDGET: Well, I tried my hand, foolishly I might add, at mountain climbing. And this was the result.

COL.LANDA: Mountain climbing? That's how you injured your leg, mountain climbing?

BRIDGET: Believe it or not, yes it is.

(stage directions) A brief moment passes between the two...THEN... The Colonel BURSTS OUT with UPROARIOUS LAUGHTER. So uproarious in fact, that it's quite disconcerting to the four saboteurs. The Colonel begins to regain his composure...

COL.LANDA: Forgive me, fraulein. I don't mean laugh at your misfortune. It's just...mountain climbing? I'm curious fraulein, what could of ever compelled you to undertake such a foolhardy endeavor?

(stage directions) The Double meaning is not lost on the German actress.

Відповідь актриси здалась Гансу настільки безглуздою і погано спланованою, що навіть він - завжди стриманий - не втримав виплеску хворобливого сміху, який виказав те, що він знає, як насправді Бріджит зламала ногу. Це не залишилося поза увагою фон Хаммерсмарк i викликало в неї доволі помітне хвилювання і відчуття невизначеності, оскільки трактувати таку поведінку Ланди можна двозначно, що додало саспенсу до ситуації їхньої розмови. У цьому випадку асоціативний підтекст виявився крізь ненавмисну невербальну комунікацію - сміх, який створив ефект напруженості та очікування.

Їжа є важливим елементом підтексту, вираженим екстралінгвально в багатьох фільмах Тарантіно. Здебільшого процес прийняття їжі асоцієються на підсвідомому рівні з безпекою, захищеністю та спокоєм, оскільки наші печерні пращури їли здебільшого гуртом біля вогню і лише у випадку відсутності небезпеки. В епізоді побиття Ведмедем-Жидом (одним з Виродків) німецького солдата ватажок банди Алдо Рейн дістає 3 торбини шматок хліба та починає їсти. Решта месників свистить і підсміюється, однак найбільш впевненим та спокійним почувається Алдо - настільки спокійним, щоб їсти під час того, як солдатові насмерть розбивають голову бейсбольною битою. У раніше згаданому епізоді посиденьок Ганса Ланди з Шошанною офіцер замовляє собі й дівчині штрудель у ресторані. Тоді, коли полковник із задоволенням та прицмокуванням поїдає страву, єврейці доводиться докладати емоційних зусиль, щоб проковтнути хоча б шматочок. Ланда почувається абсолютним домінантом у цій ситуації - він знає правду про Шошанну, дражнить іiі та маніпулює нею, а отже - він у абсолютній безпеці. Дівчина ж знаходиться на межі стресу та паніки, до того ж ій потрібно не виказати себе, тому процес споживання їжі сприймається як емоційно важкий. Перед тим, як піти, Ланда гасить сигарету об недоїдений штрудель, тим самим повністю руйнуючи відчуття безпеки дівчини та їі зону комфорту, і відразу ж після його відлучення вона заходиться сльозами. Як бачимо, їжа використовується в ролі асоціативного підтексту 3 метою натяку на те, хто 3 персонажів почувається впевнено, на кого чатує небезпека, а також хто з героїв має перевагу над іншими. 
Важливим інструментом та характерною рисою кінодискурсу Тарантіно $є$ явище перемикання мовних кодів. Варто відзначити, що у фільмі використовується чотири мови: англійська, німецька, французька та італійська, причому персонажі досить часто переходять 3 одної на іншу, що й лежить в основі перемикання кодів. Здебільшого цей прийом використовується з метою створення підтексту, а через нього - саспенсу.

Розглянемо це на прикладі першого випадку перемикання мовного коду - розмови Пер’єра ЛаПадіта з Гансом Ландою на початку фільму. Після кількох хвилин бесіди полковник просить перейти на англійську, яка виступає як лінгва франка для двох персонажів. Під час цих його слів Пер'єр виказує ледь помітне збентеження, на яке є досить серйозна причина - француз переховує у своєму будинку євреїв, які до того ж розмовляють лише французькою, а тому не розумітимуть жодного слова 3 цієї розмови, особливо якщо йтиметься про них. Власне, так $\mathrm{i}$ сталось - Ланда з самого початку знав, що сім'я ЛаПадітів ховає євреїв, ховає їх під підлогою, i використав перемикання кодів не тому, що погано володіє французькою, а тому, що англійську втікачі навряд чи розуміють:

COL. LANDA: Since I haven't heard any disturbance, I assume that while they're listening, they don't speak English?

PERRIER: Yes.

COL. LANDA: I'm going to switch back to French now, and I want you to follow my masquerade - is that clear?

Перемикання коду, двозначність слів полковника, постійне затягування розмови та відкладання висловлення справжньої мети його візиту створює відчуття напруженості та невизначеності. Коли Ланда переконується, що євреї таки не зрозуміли жодного слова 3 їх розмови та не усвідомили небезпеку, яка на них чатує - напруженість досягає піку, і це створює неперевершений ефект саспенсу. Пер'єр висловлює це невербально - він починає плакати та затинатись, а також вербально - зізнається, що переховує євреїв, а це свідчить про досягнення початкової цілі Ганса. Метою навмисного перемикання мовного коду в цьому випадку було створення напруженості та невизначеності (саспенсу), у стані яких маніпулювати співрозмовником (Пер'єром) стає простіше.

Ще одним прикладом створення саспенсу завдяки явищу перемикання мовних кодів $\epsilon$ епізод у пабі, де Виродки та Арчі Гікокс зустрілись із Бріджит фон Гаммерсмарк, однак були викриті німецьким офіцером Гелльстрьомом. Протягом усієї розмови Гелльстрьом повільно створював атмосферу напруженості вербально і все ж залишав надію Виродкам, що він таки не здогадався про те, хто вони насправді. Навіть після того, як Гікокс та офіцер навели один на одного пістолети, вони все ще продовжували вести розмову, намагаючись вирішити ситуацію, що склалась, однак піком саспенсу стає перехід Арчі з німецької на англійську:

LT. HICOX (ENGLISH): Well, if this is it old boy, I hope you don't mind if I go out speaking the King's?

MAJOR HELLSTROM (ENGLISH): By all means, Captain.

У цьому випадку, перехід на “King's language" $\epsilon$ метонімією та трактується як уособлення англійської мови, а саме “королівської англійської”. Це навмисне перемикання мовних кодів $\epsilon$ напруженим для обох сторін, оскільки Гікокс уже не намагається приховати факт того, що він британський шпигун, а отже, втрачати йому вже немає чого і він готовий до найжахливіших наслідків. Метою цього перемикання є висловлення почуття відчаю крізь лексичний підтекст, що тим самим і створює саспенс, оскільки Гельстрьом не знає, на що готовий Гікокс у такому стані та чим це завершиться для них усіх. Як і в першому випадку, ефект саспенсу герої створювали за допомогою вербальних маніпуляцій, однак його пік був досягнутий завдяки явищу навмисного перемикання мовних кодів.

Висновки та перспективи подальших досліджень. Таким чином, у процесі дослідження та аналізу нам вдалося виділити й узагальнити такі особливості кінодискурсу Квентіна Тарантіно: цілісність, широке використання підтексту, інтертекстуальність та створення ефекту саспенсу. Цілісність $є$ важливою характеристикою не лише кіно-, але й будь якого дискурсу. Що ж до кінодискурсу творів Тарантіно, то в нього ця риса набуває надзвичайно 
вагомого значення, оскільки власне його структура є доволі складною: використання багатьох мов, перемикання мовних кодів, застовування вербальних маніпуляцій, а до того ж і велика кількість сюжетних ліній, які зрештою мають об'єднатись в одне.

Підтекст у цьому кінодискурсі створюється всіма можливими способами (лексичним, ситуативним, асоціативним) із здебільшого метою маніпуляції чи насмішки або ж з метою розкриття певної інформації про мовців. Найбільше цим прийомом користується герой Ганса Ланди, оскільки його мета у фільмі - це працювати на дві сторони і ні за кого насправді, тому всі можливі вербальні, невербальні та екстралінгвальні маніпуляції - невід’ємна частина комунікативного середовища героя.

Інтертекстуальність $є$ поширеною рисою не лише в кінодискурсі творів цього конкретного режисера, але й у дискурсі загалом, у літературі, музиці та майже всіх видах мистецтва. Освіченому глядачеві ця риса допомагає зчитувати додаткову інформацію із реплік, ракурсів, кадрів чи назв, причому вона може робити вагомий внесок у розвиток персонажа чи то фільму загалом, а може не означати нічого й мати на меті лише викликання асоціації.

Створення ефекту саспенсу в кінодискурсі творів Тарантіно відбувається переважно за допомогою мовних засобів: того ж підтексту чи зміни мовних кодів, що $є$ доволі незвичним для кіно, адже зазвичай для цього використовуються саундтреки, операторська робота чи робота зі світлом, які є екстралінгвальними засобами. Однак саспенс цього фільму базується здебільшого на вербальних та невербальних елементах, у більшості під час діалогів та за відсутності екстралінгвальних компонентів (музики чи особливої гри зі світлом).

Усі ці риси притаманні кінодискурсу більшості його картин та є частиною неповторного стилю, оскільки Тарантіно виступає не лише режисером, але й сценаристом. Ці особливості виступають як засоби передачі інформації (вербальної, невербальної або ж екстралінгвальної), за допомогою якої з'являється можливість точніше інтерпретувати емоції, відчуття та враження мовців у певній ситуації, усвідомити їхнє ставлення до цих ситуацій, інших мовців чи об' єкта дискусії. Можна впевнено стверджувати, що аналіз кінодискурсу та сам факт виділення його серед інших видів дискурсу є ключовим для розуміння багатьох факторів комунікації, оскільки кіно як мистецтво $є$ засобом відтворення реальності та соціального пізнання.

Незважаючи на велику кількість публікацій у сфері кінодискурсу, подібні дослідження не втратять свою важливість та релевантність доти, доки релевантним $є$ мистецтво кіно і його здатність відображати та впливати на дійсність та комунікацію. Перспективою подальших досліджень є глибинний аналіз кінематографа не лише американських режисерів, але й українських у світлі впливу кінодискурсу на тренди в комунікації та навпаки. Зважаючи на постійну популярність екранізацій літературних робіт, релевантними були б дослідження наративної репрезентації, особливості структури та порівняння ії у конкретному кінофільмі та відповідному літературному творі. Вплив екстралінгвальних елементів, як-от прийоми монтажу на побудову наративу та цілісність кінодискурсу також залишаться релевантним у сфері наукових розвідок. Перспективним також видається дослідження кінодискурсу як акту комунікації між глядачами та режисером, під час якого передається певне повідомлення, а саме наскрізна ідея фільму чи авторський задум.

\section{References}

1. Androutsopoulos, Jannis. 2012. "Introduction: Language and Society in Cinematic Discourse". Multilingua 31: 139-154. Accessed February 3, 2020. doi: https://oi.org/10.1515/multi-2012-0007.

2. Bart, Roland. 1994. Ot proizvedeniya k tekstu. Izbrannye raboty: Semiotika. Poetika. Moskva :Progress. 413-423

3. Belykov, Vladimir and Leonid Krysyn. 2001. Sotsyolynhvystyka : uchebnyk dlia vuzov. Moskwa : Ros. hos. humanyt. un-t.

4. Bozhko, Olena. 2017. "Atmosfera «saspens» yak dominantna oznaka literaturnoho zhanru «fentezi»”. Naukovi zapysky Natsionalnoho universytetu «Ostrozka akademiia». Seriia «Filolohichna» 67: 51-54. Accessed February 3, 2020. doi: 10.25264/2519-2558-2017-67-51-54.

5. Dijk Van, Teun A. 2000. Yazyk. Poznanye. Kommunykatsyia. Blahoveshchensk: BNK im. Y. A. Boduena de Kurtene.

6. Hrydasova, Olena. 2014. "Kinodyskurs yak obiekt navchannia kinoperekladu”. Visnyk Zhytomyrskoho derzhavnoho universytetu 74: 102-107.

7. Jaeckle, Jeff. 2013. Film Dialogue. Edited by Jeff Jaeckle. London; New York : Wallflower Press. 
8. Kovalenko, Iryna. 2011. "Intersemyotycheskyi perevod v mezhkulturnom aspekte: postanovka problem". Izvestyia Volhohradskoho hosudarstvennoho pedahohycheskoho unyversyteta 2: 50-53. Accessed February 3, 2020. doi: 10.22363/2312-9182-2019-23-2399-414

9. Kovaliv, Yurii. 2007. Literaturoznavcha entsyklopediia. U 2-kh t. Kyiv : VTs «Akademiia».

10. Kristeva, Julia. 1974. La Révolution du langage poétique. L'avant-garde à la fin du XIXe siècle:Lautréamont et Mallarme. Paris : Éditions du Seuil.

11. Krysanova, Tetiana. 2014. "Osnovni pidkhody do rozuminnia poniattia «kinodyskurs»", Naukovyi visnyk Skhidnoievropeiskoho natsionalnoho universytetu imeni Lesi Ukrainky 4: 98-102.

12. Kukharenko, Valeria. 1988. Interpretatsyia teksta. Moscow: Prosveshchenie.

13. Samkova, Maryya. 2011. "Kynotekst i kynodyskurs: k probleme razgranychenyia ponyatyi". Fylologycheskye nauky. Voprosy teoryy y praktyky 1: 135-137.

14. Schmidt, Johann and Markus Kuhn. 2014. "Narattion in Film". In Handbook of narratology, edited by Peter Hühn, Jan Christoph Meister, John Pier, Wolf Schmid. Volume 1: $384-405$. Berlin: De Gruyter.

15. Slyshkyn, Gennadyi and Marya Efremova. 2004. Kynotekst: opyt lingvokulturologycheskogo analyza. Moskwa: Vodolei Publishers.

16. Tarantino, Quentin G. 2009. Inglourious Basterds. Film script. IMSDb. https://www.imsdb.com/scripts/ Inglourious-Basterds.html (accessed September 11, 2020).

17. Tsyvyan, Yuryi. 1984. "K metasemioticheskomu opisaniyu povestvovanyia v kinematografe". Trudy po znakovym systemam. Uchenye zapiski. Tartus. gos. un-ta 17: 109-121.

18. Voroshylova, Marya. 2007. "Kreolizovannyi tekst : kinotekst". Politicheskaya lingvistika 22: 106-110.

19. Wollen, Peter. 1976. Signs and Meaning in the Cinema. Bloomington: Indiana University Press, 116-154.

20. Zaichenko, Svetlana. 2013. "K voprosu o znakovoi neodnorodnosti kinodyskursa". Vestnik Chelyabinskogo gosudarstvennogo universiteta 2: 96-99.

21. Zaretskaia, Anna. 2012. "Osobennosti realizatsyi podteksta v kinodiskurse“. PhD diss., Cheliabynsk: Abrys.

22. Zviereva, Olha. 2006. "Suchasnyi kinodyskurs: spetsyfika ta osoblyvosti katehorialnoho potentsialu". Naukovi zapysky KhEPU 4: 114.

Малимон Леся, Барило Яна. Лингвокогнитивные особенности кинодискурса произведений Квентина Тарантино (на материале фильма "Бесславные ублюдки"). Статья посвящена рассмотрению особенностей кинодискурса режиссёра Квентина Тарантино на материале фильма "Бесславные ублюдки”. Понятие “кинодискурс" рассматривается как комплексное, включающее в себя множество аспектов и составляющих, а именно вербальных, невербальных и экстралингвистических. В статье анализируются специфические черты кинодискурса данного фильма как отдельно взятые, а также как формирующие подлинный режиссёрский стиль и повторяющиеся во многих фильмах Тарантино. По мнению авторов, анализ кинодискурса и сам факт выделения его среди других видов дискурса являются ключевыми для понимания многих факторов коммуникации, поскольку кино как искусство является средством воспроизведения реальности и социального познания. Последние, в свою очередь, поддаются влиянию кинодискурса. В статье доказывается, что главными и ярко выраженными чертами кинодискурса есть интертекстуальность, целостность, широкое использование подтекста и создание эффекта саспенса, причём большинство этих черт являются взаимосвязанными, а также выступают как результат влияния некоторых языковых явлений. Эти особенности виступают как средства передачи информации (вербальной, невербальной или экстралингвистической), помогают правильно интерпретировать внутренние чувства говорящих в определенной ситуации и понять их видение этих же ситуаций, других говорящих или объекта дискуссии. Авторы отмечают, что все ранее упомянутые черты, а именно: использование переключения языковых кодов, применение невербальных манипуляций, большое количество сюжетных линий, которые должны объединиться в одно целое, так или иначе формируют структуру, стиль и понимание кинокартины, а собственно кинотекст является важной вехой в сложной синтетичной структуре кино рядом с такими значимыми для смисловой и эстетической завершенности экстралингвистическими составляющими, как визуальный ряд, звуковая информация, визуальные и механические специальные эффекты, компьютерная графика и др. Статья обращает внимание на важность анализа кинодискурса и понятие кинотекста в свете увеличения популярности, релевантности, влияния, а поэтому и важности искусства кино, которое на сегодня является не только развлечением или частью массовой культуры, но и средством влияния на коммуникацию и социальное познание, а отдельные фильмы являются важной составляющей мирового киноресурса и кинодискурса.

Ключевые слова: кинодискурс, подтекст, саспенс, интертекстуальность, языковой код.

Malimon Lesia, Barylo Yana. Linguo-cognitive peculiarities of Quentin Tarantino's film discourse (on the materials of the film "Inglourious Basterds"). The article deals with the means of analysing of peculiarities and specific features of Quentin Tarantino's film discourse on the materials of the film "Inglourious Basterds". The term "film discourse" is treated as a complex one, which includes plenty of aspects, i.e. verbal, non-verbal and extralinguistic. The article analyses and draws attention to the specific film discourse characteristics, which are taken individually and as those forming the original directing style and being present in most of the director's films. Authors argue that film discourse itself and the fact that it is distinguished among other discourse types is crucial to the understanding of plenty of communication factors, since cinematography as an art is a tool for the reflection of reality and social cognition. The latter, on their turn, are easily influenced by film discourse. The article proves that the main and the most particular film discourse features of this film are 
intertextuality, cohesiveness, wide use of the subtext, creation of the effect of suspense, while most of these features stand as interconnected and as a result of the influence of some language phenomena. These characters and features stand as a tool for the transmission of information (verbal, non-verbal, extralinguistic), assist in the correct interpretation of the speaker's feelings in a certain situation and to understand their vision of this situation, other speakers and the object of discussion. The authors note that all the previously mentioned features one way or another influence and form the structure, style and the perception of the film, and the film text itself is an important milestone in the complex synthetic film structure, alongside with such extralinguistic components, which are crucial to meaningful and aesthetic completeness, as visual information, sound, visual and mechanical special effects, computer graphics, etc. The article explores and draws attention to the importance of the analysis of film discourse and the concept of "film text" in the light of increasing popularity, relevance, influence, and therefore the importance of the art of cinematography, which is treated currently not only as an entertainment, or a part of popular culture, but also as a tool of influence on communication and social cognition, and therefore individually taken movies are an important part of the world film resource and film discourse.

Key words: film discourse, subtext, suspense, intertextuality, language code.

DOI: https://doi.org/10.32782/2410-0927-2020-12-21

УДК $811.111^{\prime} 22 ’ 42$

Лариса Макарук

\section{СТРУКТУРА, СЕМАНТИКА ТА ФУНКЦЙНЕ ПРИЗНАЧЕННЯ ДУЖОК ТА ЦИФР У СУЧАСНОМУ АНГЛОМОВНОМУ МАСМЕДІЙНОМУ КОМУНІКАТИВНОМУ ПРОСТОРІ}

У роботі проаналізовано дужки та цифри як невербальні елементи, що є складниками однієї з груп, які загалом охоплюють невербальні та паравербальні компоненти, які функціонують у сучасному англомовному масмедійному комунікативному просторі. До аналізованої нами групи «Непіктографічні та нефотографічні елементи» входять знаки пунктуації; діакритичні знаки; типографічні й інші допоміжні знаки; цифри (числа); математичні символи; абревіатури. У цій розвідці докладно висвітлено специфіку дужок та цифр як інтегральних модусів масмедійного середовища.

Окреслено їх семантичні та структурні особливості, ідентифіковано функційне навантаження, обгрунтовано їх роль та призначення у сучасному англомовному масмедійному комунікативному просторі. Крім традиційного використання круглих дужок як знаків пунктуації у складі тексту, які додатково пояснюють зміст, уточнюють сказане поза текстом в дужках, активно залучають квадратні, фігурні, атипові видозмінені (контекстуально залежні).

Окрім типових функцій, дужки виконують й низку атипових будучи різними за розмірами, формою та кількісним складом, зокрема: уточнювальну, лаконічну, дейктичну, змістово-розгалужувальну, атрактивну, змістовидільну, акцентування уваги, змістотворчу, структурувальну, компресивну, а також указують на ініціальну та фінальну частини тексту.

Встановлено, що в англомовному масмедійному комунікативному просторі цифри використовують замість лексем, графем і морфем. Переважно, вони компресують кількість традиційних графічних елементів, що входять до складу однієї лексеми. Трапляються випадки, коли замість словесного модусу використовують цифровий, який виконує роль лексеми. Цифрові модуси також бувають різних форм та розмірів й мають різне кольорове забарвлення. Виявлено, що найпоширенішим є залучення цифр чотири та два, які заміщують piзні лексеми (for, four, two, to тощо).

Ключові слова: масмедіа, комунікативний простір, дужки, цифри, функція.

Вступ. Закономірно, що науковий опис особливостей масмедійного комунікативного простору як мультимодального явища, в якому співіснують вербальні, невербальні та паравербальні засоби, потребує нових поглядів на функціонування писемного мовлення у прагматичному, соціокультурному і лінгвостилістичному вимірах. У зв'язку з цим особливої значущості набуває всебічне дослідження різних аспектів мультимодальності сучасного спілкування, дослідженню яких присвячені роботи вітчизняних і зарубіжних учених, зокрема Дж. Беземера [6], К. Джевіт [7], Г. Кресса [8], Т. ван Лівена [11], С. Норріс [9], К. О’Халлоран [10], В. А. Єфименко [3], М. А. Карп [4], О. В. Білецька [1], О. С. Маріна [5], Н. Я. Град [2].

Незважаючи на значну кількість розвідок, присвячених масмедійній царині, відкритим залишається питання про структурно-функційні, комунікативно-прагматичні, лінгвостилістичні та соціокультурні аспекти взаємодії вербальних, невербальних і паравербальних засобів, що й

(C) Макарук Л., 2020 